\title{
AN ELECTROPHYSIOLOGICAL INVESTIGATION OF SKELETAL MUSCLE IN HUMAN CHRONIC CHAGAS' DISEASE
}

OLGA P. BANZ

G. G. ARISTIMUNO
A. F. RATUSNU

E. H. O'NEILL

R. E. P. BICA

In a preliminary investigation carried out on patients with chronic Chagas' disease, Pagano et al. ${ }^{7}$ demonstrated that some skeletal muscle denervation occurs in this condition; however they were unable to individualize the site of lesion within the motor unit (m.u.). The present investigation has been design to explore further the denervation which can be found in these patients and an attempt has been made to localize the site of the m.u. where the original lesion occurs.

A partial account of this work has been given elsewhere 8

\section{MATFRIAL AND METHODS}

90 patients aged between 7 and 58 years, with chronic Chagas' disease, were studied. All them were judged to be healthy on clinical examination and the diagnosis was based on the positiveness of, at least, two out of three spectfic serum tests for Chagas' disease. Coincidental causes of denervation were eliminated by excluding patients over the age of 6012 and any who had had toxic or metabolic disorders known to be associated with neuropathy.

A total of 270 healthy subjects served as controls for one or more electrophysiological test.

The following investigations were carried out: 1) measurements of maximal nerve motor and sensory conduction velocities as well as motor terminal latencles were made in the manner described in previous papers 11; 2) responses of the thenar muscles to repetitive stimulation of the median nerve (one second tratns of supramaximal stimuli were glven at frequencies of 3,10 and $30 \mathrm{~Hz}$ on the median nerve at the wrist, while the muscle evoked response were recorded at the thenar muscles with surface electrodes); 3) in a few patients (8 subjects) quantification of the end-plate noise was carried out by employing a tungsten electrode inserted within the extensor digitorum brevls (edb) muscle end-plate area in the manner described by O'Neill and Sica 5; 4) estimations of the numbers and sizes of operative m.u. were performed within the thenar, hypothenar, soleus and edb muscles following the techniques decribed previously 2,9,12; 5) the amount of excitability coming down from the supraspinal structures which is imposed onto the spinal alpha motoneurones was tested in all the patients by applying the excitability coefficient (ec)10. This investigation was carried out in the thenar muscles inervated by the median nerve.

Section of Clinical Hectroneurophysiology, Hospital Ramos Mejia, Buenos Aires. Argentina. 
Treatment of the results: - Throughout the text means are given with 1 S. D. Differences between mean values were calculated by employing the Student " $t$ " test.

\section{RESULTS}

1) Nerve conduction studies - In all patients the maximal motor conduction velocities in the median, ulnar and deep peroneal nerves were within the normal range for this laboratory; furthermore the mean velocities were very close to the control values and did not differ significantly from them (Table 1).

A comparison was also made of the motor terminal latencies in the control and Chagas populations, once again controls and patients did not differ significantly (Table 1).

The conduction velocities of the fastest conducting sensory fibres were. measured in the median and ulnar nerves. All the patients had values within the normal range for this laboratory and there was no significant difference between the means for the two populations (Table 2).

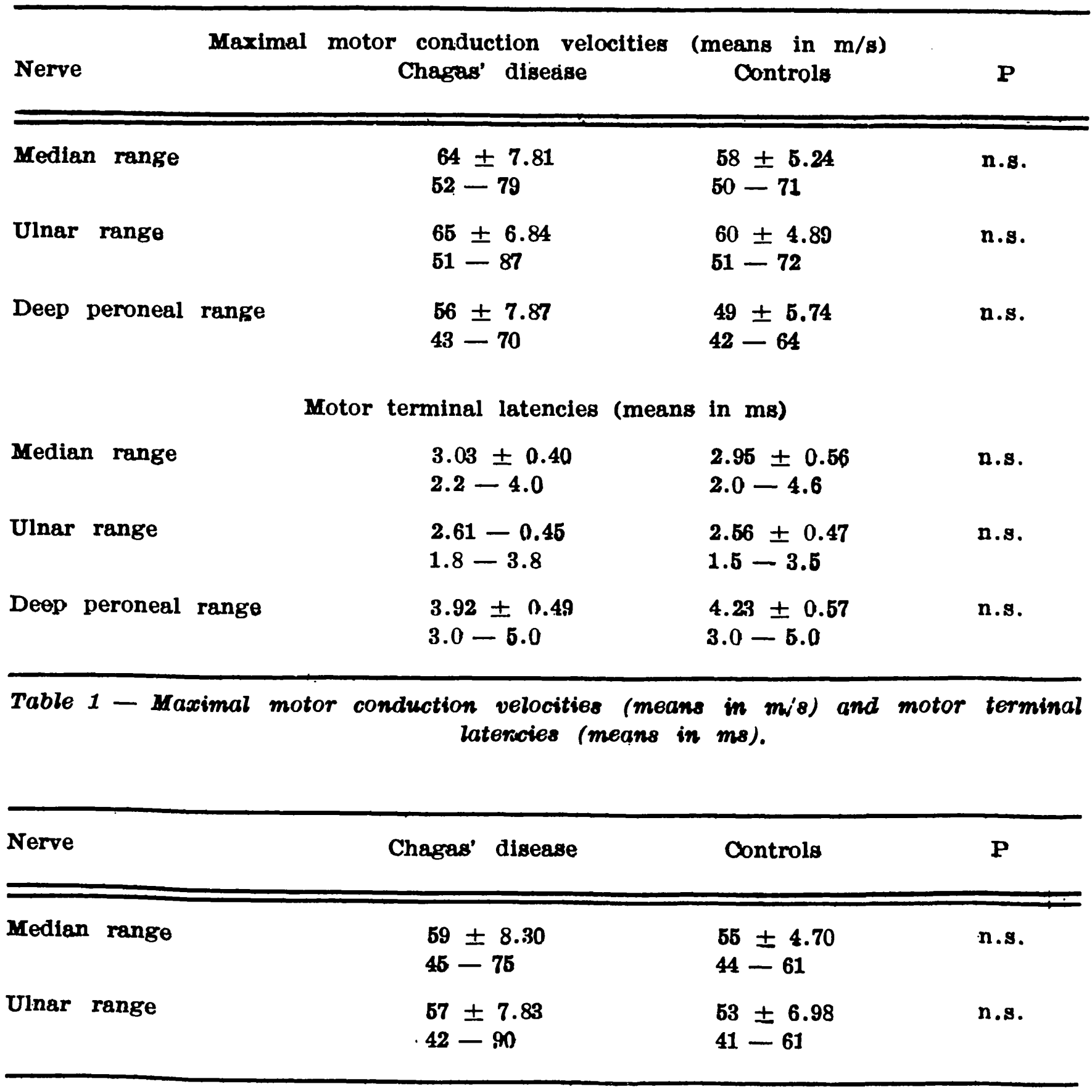


2) Muscle responses to repetitive norve stimulation - No decremental responsea were observed in any of the tested patients.

3) Quantification of the erd-plate noise - In 8 patients with a reduced number of m.u. in the edb muscle, the frequency of the small monophasic negative potentials (smnp) which can be picked up at the edb end-plate area during 30 minutes recording was much higher than the control population.

This behaviour paralelled a group of 5 denervated patients of known aetiology who were studied for comparison (Controls, mean $2.31 \pm 1.39 \mathrm{smnp} / \mathrm{s}$; denervation, mean $7.18 \pm 1.72 \mathrm{smnp} / \mathrm{s} ;$ Chagas, mean $7.65 \pm 2.33 \mathrm{smnp} / \mathrm{s} . P(\mathrm{c}-\mathrm{d})<.01 ; \mathrm{P}$ (c $-\mathrm{Ch})$ $<.01 ; \quad P(d-C h)$ n.s. $)$.

4) Estimated numbers and sizes of m.u. - The numbers of functional m.u. were diminished in some patients. Apparently the susceptibility of the different muscles explored to denervation was different; the loos of units was far more frequent in the thenar muscles, 54\% of the studied population showed values below the lower
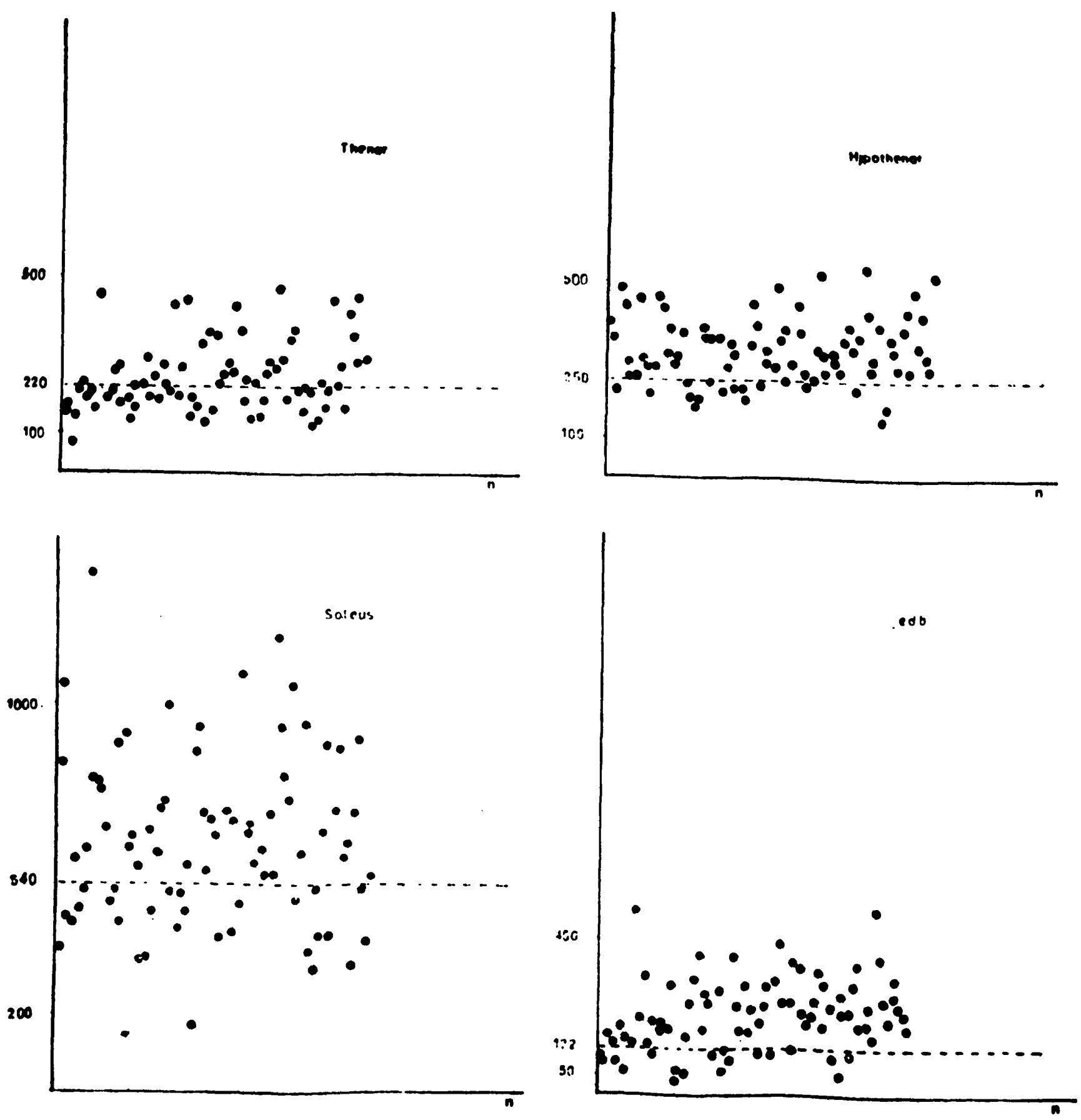

Fig. 1 - Number of motor units in patients with chronic Chagas disease. Ordinate, number of units; abscisae, number of patients. Interrupted line signals the lower limit of the control population 
limit of the control group, while the hypothenar muscles were quite well preserved.

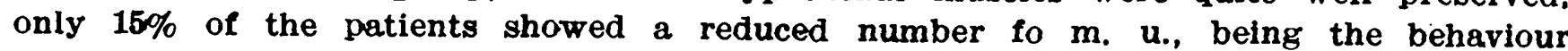
of the soleus and edb muscles intermedious (37\% of the patients had a diminished number of m.u. in the soleus and $21 \%$ in the edb).

Most of the patients showing reduction of the numbers of operative m.u. lied just below the lower limit of the control population, a few patients showed severe denervation in the thenar, soleus and edb muscles (Figure 1).

In each patient the sizes of individual m.u. were measured. To make a moro detailed analysis of the sizes of the m.u. potentials, they were divided into 3 groups for each particular muscle. The first group comprised those patients with reduced number of units; the second those with normal number of units in the studied muscle, but reduced number in other muscles and, finally the third group those patients with normal number of units in the analyzed as well as in the other investigated muscles. By pooling all the results and calculating the mean, it was found that the patients first group differed significantly from the other two patients groups and controls, while the last two patients groups and controls did not differed significantly among them (Table 3 ).

\begin{tabular}{|c|c|c|c|c|c|c|c|}
\hline Muscles & I & $\mathbf{P}$ & II & $\mathbf{P}$ & III & $\mathbf{P}$ & IV \\
\hline thenar & $\begin{array}{l}0.32 \\
\pm 0.18\end{array}$ & n.s. & $\begin{array}{l}0.36 \\
\pm 0.17\end{array}$ & n.s. & $\begin{array}{l}0.33 \\
\pm 0.24\end{array}$ & $<.001$ & $\begin{array}{l}0.77 \\
\pm 2.48\end{array}$ \\
\hline hypothenar & $\begin{array}{l}0.29 \\
\pm 0.15\end{array}$ & n.s. & $\begin{array}{l}0.32 \\
\pm 0.21\end{array}$ & n.s. & $\begin{array}{l}0.28 \\
+0.20\end{array}$ & $<.001$ & $\begin{array}{l}0.47 \\
\pm 0.24\end{array}$ \\
\hline soleus & $\begin{array}{l}0.14 \\
\pm 0.08\end{array}$ & n.s. & $\begin{array}{l}0.13 \\
\pm 0.09\end{array}$ & n.s. & $\begin{array}{l}0.14 \\
\pm 0.20\end{array}$ & $<.001$ & $\begin{array}{l}0.26 \\
\pm 0.18\end{array}$ \\
\hline edb & $\begin{array}{l}0.46 \\
\pm 0.30\end{array}$ & n.s. & $\begin{array}{l}0.46 \\
\pm 0.36\end{array}$ & n.s. & $\begin{array}{l}0.49 \\
\pm 0.35\end{array}$ & $<.001$ & $\begin{array}{l}1.20 \\
\pm 0.92\end{array}$ \\
\hline
\end{tabular}

Table 3 - Mean size of motor units. The sizes of m.u. have been expressed as \% of the amplitude of the maximal $M$ wave: $I=$ group of patievits with normal number of units in the studied muscle asd in the other investigated muscles; II = group of patients with normal number of units in the studied muscle, but reduced number in other investigated muscles; III = controls; $I V=$ group of patients with reduced number of units in the studied muscle (see text).

5) Spinal alpha motoneurone excitability - The patients spinal alpha motoneurone excitability, as tested by the ec, did not differ significantly. from the control population when it was investigated in those patients showing reduced number of m.u. within the thenar muscles (Patients, mean: $15.53 \pm 10.03$; Controls, mean: $17.47 \pm$ 8.19; P: n.s.).

\section{DISCUSSION}

Of the various observations made in this study, the most significant one was that many m.u., in some patients, had completely ceased to function, while others were abnormally large. This sort of behaviour has been previously found in other well-known denervatory conditions ${ }^{4}$ and furnishes, perhaps, the 
strongest evidence for an involvement of the peripheral nervous system in chronic Chagas' disease.

The enlarged sizes of many of the remaining units have special significance, for such enlarged potentials could only have resulted if potentially healthy muscle fibres had lost their original inervation and had subsequently acquired a satisfactory nerve supply.

The size of a m.u. can be considered as an index of the functional normality of the corresponding motoneurone, thus a healthy motoneurone is able to acquire denervated muscle fibres by axonal sprouting increasing the size of its m.u.; conversely, that m.u. which is unable to enlarge its territory belongs to a dysfunctional or "sick" motoneurone ${ }^{3}$. In previous papers ${ }^{3}$ impaired neuromuscular transmission and prolonged terminal latency were thought to constitute further signs of dysfunction. The lack of both features in chronic Chagas' disease indicates the abence of dysfunctional motoneurones within the spinal cord of these patients.

From the considerations presented above, it may be inferred that in those patients with loos of operative m.u. two types of motoneurones may be functionally distinguished at the time of the investigation: the first one comprises those motoneurones whose m.u. have been enterily destroyed, while the second population would be composed by absolutly healthy neurones.

If the interpretation of our results is correct, then it has to be accepted that in these patients there has been a sudden and non-progressive damage of the spinal alpha motoneurones during the development of the disease. It is probable that after this episode most of the motoneurones were able to recover completely, whlie just a few of them died away.

We do not know how long will take a motoneurone to recover in this condition, however the high frequency of the small negative monophasic. potentials recorded at the edb end-plate area, which favours an increased amount of neuromuscular synaptic contacts per unit area ${ }^{6}$ allows some speculations. This finding may be explained by accepting that during the period of motoneurones damage many muscle fibres lost their inervation and were adopted by sproutings of axons belonging to undamaged motoneurones; later on, while some of those damaged motoneurones died away, others were able to recover capturing the muscle fibres previously adopted by other neurone. It is known that mammalian skeletal muscle fibre normally receives one single inervation but will accept a foreign axonal branch when its original inervation becomes inactive; however if the original inervation is allow to grow again into the muscle and reaches its original muscle fibres, it will establish functional effective synaptic contacts without repressing the adoptive innervation 1. Therefore, in these conditions, a muscle fibre may have two synaptic contacts, both functional. This will increase the number of neuromuscular junctions per unit area and then, the frequency of the small negative potentials picked up at the synaptic region ${ }^{\circ}$. 
The postulated sequence of events after the spinal motoneurone damage in Chagas' disease is shown diagrammatically in figure 2. From this figure it can be seen that the present investigation has been carried out in state $V$. when the loos of units, if present, can be recognize and only healthy, undamaged m.u. can be excited.
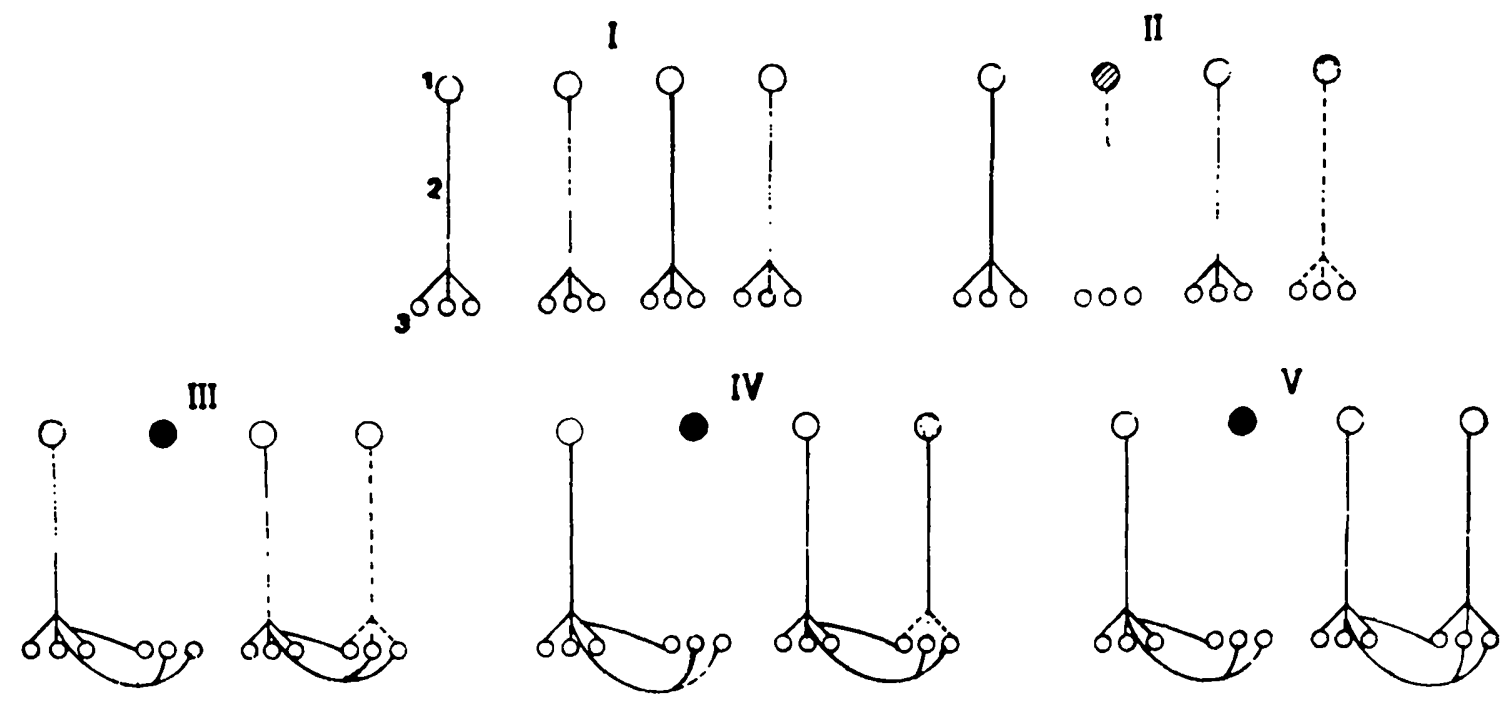

Wig. 8 - Postulated sequence of events after spinal motoneurons damage in Chagas' disease. 1 motoneurone soma; $2=$ axon; $S=$ muscle fibres. Shadowo neurones signal sick neurones. Dark neurones signal dead neuromes.

Finally, one more question remains to be answered: could the looses of m.u. be due to trans-synaptic degeneration of the spinal alpha motoneurone soma secondary to degenerative changes of supraspinal structures which have been described in chronic Chagas' disease? ${ }^{13}$. To answer this problem particular care was taken in the examination of each patient rejecting everyone who had evidences of central nervous system damage. Furthermore, the ec which is an index of the amount of the descending excitatory inputs coming down onto the motoneurone soma, was normal for all the patients investigated.

In conclusion, the present study has shown that in some patients with chronic Chagas' disease there are looses of m.u. due to a sudden and non-progressive damage of the spinal alpha motoneurone soma which, in most instances, is mild, below the clinical recognition, and well compensated by sprouting of the surviving motoneurones. However, the underlying mechanisms in neuronal degeneration cannot be searched by the present technique.

\section{SUMMARY}

An electrophysiological study has been made of the thenar, hypothenar, soleus and extensor digitorum brevis muscles and their inervation in 90 patients with chronic Chagas' disease. Some of them showed a reduced number of functional motor units with increased size of many of the surviving units. No decremental muscle response was found to repetitive nerve stimulation. Motor 
and sensory conduction velocities as well as motor terminal latencies were on the normal range. These findings suggested that the muscle changes resulted from a primary defect of the alpha spinal motoneurone soma.

\section{RESUMFN}

\section{Estudio electrofisiológico del músculo esquelético en la enfermedad de Chagas crónica.}

90 pacientes afectados por enfermedad de Chagas crónica fueron estudiados electrofisiológicamente procediéndose a cuantificar las unidades motoras actuantes en los músculos de la eminencia tenar, eminencia hipotenar, soleo y extensor corto de los dedos. Se halló que muchos de ellos poseian un número reducido de unidades, en tanto que buena parte de las sobrevivientes mostraban su tamaño aumentado. No se encontró alteración en los valores de velocidad de conducción nerviosa motora o sensitiva ni tampouco en las cifras de latencia residual motora. La respuesta muscular al estímulo repetitivo del nervio fué igualmente normal. Los hallazgos hechos sugirieron que las alteraciones musculares halladas en estos pacientes pueden obedecer a la existencia de un defecto primario en el soma de la motoneurona alfa medular.

\section{REFERENCES}

1. FRANK, E.; JANSE, J. K. S.; LOMO, T. \& WrSTGAarD. W - Mantained function of foreign synapses on hyperinervated skeletal muscle fibres of the rat. Nature 247:375, 1974.

2. McCOMAS, A. J.; FAWCETT, P. R. W.; CAMPBELL, M. \& SICA, R. E. P. Electrophysiological estimations of the number of motor units within a human muscle. J. Neurol. Neurosurg. Psychiat. (London) 34:121. 1971.

3. MCCOMAS, A. J.; SICA, R. E. P. \& CAMPBELL. M. - "Sick" motoneurones: a unifying concept of muscle diseases. Lancet I:321, 1971.

4. McCOMAS, A. J.; SICA, R. E. P.; CAMPBELE, M. \& UPTON, A. R. M. Functional compensation in partially denervated muscles. J. Neurol. Neurosurg. Psychiat. (London) 34:453, 1971.

5. O'NEILL, E. M. \& SICA R. E. P. - In vivo recording of neuromuscular synaptic activity in human subjects. Medicina (Buenos Aires) 37:239, 1977.

6. O'NEILL E. M. \& SICA, R. E. P. - Recording of neuromuscular synaptis activity in healthy subjects and in patients with neuromuscular disease. Medicina (Buenos Aires). In press.

7. Pagano, M. A.; ARIStimuno, G. G.; BAsso, SUSANA; COLOMBI, A. \& SICA, R. F. P. - Electromyographical findings in human chronic Chagas' disease. Arq. Neuro-Psiquiatria (Săo Paulo) $36: 316,1978$.

8. SANZ, OLGA P.; SICA, R. E. P.; COLOMBI, A.; O'NEILL, M. A.; PAGANO, M. A. \& ARITIMUNO; G. G. - Despoblación de neuronas motoras alfa en la enfermedad de Chagas crónica. XXII Reunión de la Sociedade Argentina de Investigación Clínica, Mar del Plata, Noviembre 1977. Resumenes de comunicaclones. Medicina (Buenos Aires) 87:651, 1977. 
326 ARQ. NEURO-PSIQUIATRIA (BAO PAULO) VOL. 36, No 4, DEZEMBRO, 1978

9. SICA, R. E. P.; McCOMAS, A. J.; UPTON, A. R. M. \& LONGMIRE, D. - Motor unit estimations in the small muscles of the hand. J. Neurol. Neurosurg. Psychiat. (London) 37:55, 1974.

10. SICA, R. F. P.; McCOMAS, A. J. \& UPTON, A. R. M. - Impaired potentiation of $H$ reflexes in patients with upper motoneurone lesions. J. Neurol. Neurosurg. Psychiat. (London) 34:712, 1971.

11. SICA, R. E. P. \& SANZ, OLGA P. - Neuropathy in-myotubular or centronuclear myopathy. Arq. Neuro-Psiquiatria (8\&io Paulo) 33:128, 1975.

12. SICA, R. E. P.; SANZ, OLGA P. \& COLOMBI, A. - The effects of ageing upon the human soleus muscle: an electrophysiological study. Medicina (Buenos Aires) $36: 443,1976$.

13. VERgUEIRO FORJAZ, S. - Aspectos neurologicos da doença de Chagas: sistema nervoso central. Arq. Neuro-Psiquiatria (S\&o Paulo) 25:175, 1967

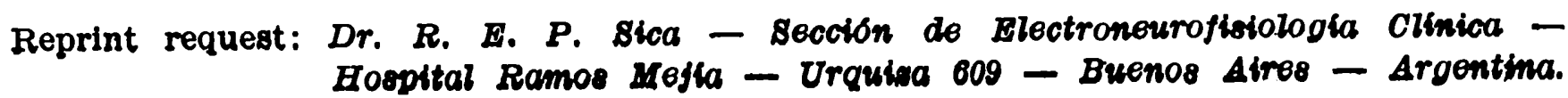

